\title{
Bioengineering functional copolymers. XII. Interaction of boron-containing and PEO branched derivatives of poly(MA-alt-MVE) with HeLa cells
}

\author{
Mustafa Türk $^{1}$, Zakir M. O. Rzayev ${ }^{2, *}$, Gülcihan Kurucu ${ }^{2}$ \\ ${ }^{1}$ Department of Biology, Faculty of Science and Art, Kırıkkale University, Yahsihan, 71450 Kirikkale, Turkey \\ ${ }^{2}$ Department of Chemical Engineering, Faculty Engineering, Hacettepe University, Beytepe, 06800 Ankara, Turkey; Correspondence \\ author: zmo@hacettepe.edu.tr
}

Received 20 October 2009; revised 20 November 2009; accepted 11 November 2009.

\begin{abstract}
Novel boron-containing bioengineering copolymer and its a-hydoxy-w-methoxy-poly(ethylene oxide (PEO) macrobranched derivatives were synthesized by (1) partially amidolysis of poly(maleic anhydride-alt-methyl vinyl ether) with ethanolamine ester of diphenylboronic acid and (2) esterification of synthesized B-containing copolymers with PEO. They had a combination of hydrophilic/hydrophobic linkages, free carboxylic groups, positive charges and an ionized organoboron linkage as antitumor sites, along with an ability to interact with HeLa cells. The structure, composition and properties (cytotoxicity and antitumor activity) of synthesized copolymers were investigated. In vitro cytotoxicity results, obtained by the fluore scence microscopy measurements indicate that unlike the virgin copolymer, boron-containing and PEO macrobranched derivatives exhibit higher antitumor activity. It was found that organoboron copolymer exhibits the most apoptotic and necrotic effects against HeLa cells whereas a minor effect relative to cancer cells was observed on L929 Fibroblast cells.
\end{abstract}

Keywords: Synthesis; Organoboron Copolymers; Structure-Property Relations; Cytotoxicity; Antitumor Activity; Apoptotic Effect

\section{INTRODUCTION}

The bioengineering functional polymers exhibit the characteristics of 1) alternating and random copolymers of maleic anhydride (MA) and 2) poly(ethylene oxide) (PEO), as well as 3) PEO grafted functional macromolecules. They are of great interest for many researchers due to their nontoxic, cell-compatible, biodegradable, stimuli-responsive properties, and therefore, a wide range of biomedical and bioengineering applications exist as drug or enzyme carriers and biomacromolecular conjugates both in diagnostics and chemotherapy as effective antitumor agents [1-8]. It is known that these copolymers can be regarded as pre-activated polymers due to the presence of anhydride moieties susceptible to the reaction with a primary amine of a biomolecule [9]. The alternating copolymers of maleic anhydride (MA) with methyl vinyl ether (MVE) or divinyl ether (DVE) were utilized in various applications in diagnostics $[10,11]$ and in chemotherapy as effective antitumor agents [8]. Poly (MA-alt-DVE), known as pyran copolymer is one of the well known bioengineering polymers having a wide range of biological activity. It processes antitumor, antiviral, antibacterial and antifungal activities, induces interferon formation, and acts as an anticoagulant and anti-inflammatory agent $[8,12-17]$. Hirano et al. $[18,19]$ reported that the poly (MA-alt-DVE) conjugated with bovine erythrocyte superoxide dismutase (SOD) is resistant against the proteolytic enzymes in serum, and shows a prolonged half-life in vivo. They established an increase in half-life after intravenous injection, as well as its decreased immunogenicity [19]. It was demonstrated that the copolymer-SOD conjugate shows anti-inflammatory effect against rat re-expansion pulmonary edema at the first step of leukocyte adhesion [15]. Maeda [20] discussed the development and therapeutic potential of prototype macromolecular drugs for use in cancer chemotherapy an artificial bioconjugate of neocarzinostatin (NCS) and poly(maleic acid-alt-styrene) copolymer. The biological response-modifiying effects, the mechanism of a tumor "enhanced permeability and retention" effect and the tumor-targeting mechanism of NCS-copolymer conjugate were also discussed. According to the author, a principal advantage in the use of this bioconjugate is the potential for a reduction or elimination of toxicity.

The copolymers of fumaric, citraconic and itaconic 
acid and their derivatives as isostructural analogues of MA, as well as copolymers of some $N$-substituted maleimides can also included to class of bioengineering polymer systems. Cam et al. [21] evaluated the in vitro cytotoxicities of glycinylmaleimide (GMI) copolymers using K-562 human leukemia cells and HeLa cells. They also evaluated the in vitro antitumor activities of copolymers against mice bearing sarcome 180. Monomeric GMI and its copolymers showed higher antitumor activity than well known 5-fluorouracil (5-FU) at any dosage tested.

One the other hand, growing interest and much effort have been also focused on the synthesis of organoboron low molecular-weight functional compounds, biopolymer and drugs with boron ligands and evaluation of their suitability for the bioengineering applications. Aromatic boronic acid and its functional derivatives, and some functionalized carboranes have become an very important class organic compounds, which are utilized in a variety of biological and medical applications, such as carbohydrate recognition [22], neutron capture therapy for cancer treatment as effective tumour-targeting agents [23,24], especially for brain tumours [25,26], and protease enzyme inhibition [27]. Kataoka et al. [28-32] synthesized a novel water-soluble polymer with lectin-like function by introducing phenylboronates, as sugar -recognizing moieties, into the side-chain of poly ( $N, N$-dimethylacrylamide) $[28,29]$. According to the authors, at physiological $\mathrm{pH}$ medium, phenyl-boronates form an appreciably stable complex with sialic acid (Neu5Ac), a chacteristic anionic carbohydrate on the surface of the plasma membranes [30,31]. Authors suggested that boronate-containing polymer may be an effective immune-adjuvant for the indu ction of lymphokine-activatd killer (LAK) cell [31]. They also demonstrated that the copolymers of 3-acry- lamidophenylboronic acid and dimethylacrylamide with different compositions coated onto solid substrates support function as synthetic mitogens for mouse lymphocytes [32].

However, a wide range of functional polymer synthesis techniques can be utilized for the design of more effective synthetic routes to prepare new B-containing bioengineering polymers, especially copolymerization of organoboron monomer and chemical modification of biocompatible polymers with organoboron reactive compounds and monomers. Several researchers synthesized some bioengineering copolymers containing phenylboronic acid linkages by radical copolymerization and chemical modification methods, which are exhibit glugose-, RNA- and DNA-sensitive behavior [33-36]. Recently, we report the synthesis and chracterization of organoboron copolymers by complex-radical copolymerization of $p$-vinylphenylboronic acid with $\mathrm{N}$-isopropylacrylamide (NIPA), maleic and citraconic anhydrides, maleimide and chemical modification of poly(NIPA-
rand-MA)s with organoboron amine, as well as synthesis of supramacromolecular poly(ethylene imine) macrocomplexes and PEO long branched derivatives of organoboron copolymers having stimuli-responsive and high HeLa cell transfection behavior [37-40].

The objective of this work is to develop novel boroncontaining functional copolymers with antitumor activity. In the present article, results of synthesis and characterization of a new generation of biocompatible boron-containing functional macromolecules having a combination of hydrophilic and hydrophobic segments, free carboxylic groups, positive charges and an ionized linkage as antitumor sities, along with an ability to conjugate with cancer cells were described and discussed. These organoboron copolymers were synthesized by 1) partially amidolysis of bioengineering alternating copolymer of maleic anhydride (MA) and methyl vinyl ether (MVE) with ethanolamine ester of diphenylboronic acid (EAPB) and 2) chemical modification (esterification) of synthesized organoboron copolymer with $\alpha$-hydoxy- $\omega$-methoxy-poly (ethylene oxide (PEO). Special attention was paid to the role of structural effects, especially to the influence of organoboron linkage, for the interaction of organoboron functional copolymers with HeLa cells and to the evaluation of citotoxisity and antitumour activity by using a combination of various methods such as statistical, hematoxylen/eosin staining, apoptotic and necrotic cell indexes, and M30 immunostaining analyses.

\section{MATERIALS AND METHODS}

\subsection{Materials}

Ethanolamine ester of diphenyl boronic acid (EAPB) (Sigma-Aldrich, Germany) was purified by recrystallization from anhydrous ethanol: m.p. $193.5^{\circ} \mathrm{C}$ (by DSC). ${ }^{1} \mathrm{H}$ NMR spectra $(\delta, \mathrm{ppm})$ in $\mathrm{CHCl}_{3}-\mathrm{d}_{1}: \mathrm{CH}_{2}-\mathrm{O} 1.49$, $\mathrm{CH}_{2}-\mathrm{NH}_{2}$ 2.96, and 7.38-7.40 (1H), 7.19-7.24 (2H) and 7.13-7.16 $(2 \mathrm{H})$ for protons of $p$-, $o$-and $m$-positions in benzene ring, respectively. Poly(maleic anhydride-altmethyl vinyl ether), poly(MA-alt-MVE) (C1) (SigmaAldrich, Germany): $M_{\mathrm{n}} 80,000$ g.mol ${ }^{-1}, T_{\mathrm{g}} 148^{\circ} \mathrm{C}$ (by DSC); ${ }^{1} \mathrm{H}$ NMR spectra $(\delta, \mathrm{ppm})$ in DMSO-d $\mathrm{d}_{6}: \mathrm{CH}_{2} 1.23$, $\mathrm{CH}-\mathrm{O} 2.11, \mathrm{O}-\mathrm{CH}_{3} 2.08$ and $\mathrm{CH}-\mathrm{CH} 3.38$. $\alpha-\mathrm{Hydoxy}-\omega-$ methoxy-poly(ethylene oxide) (Fluka; PEO, $M_{\mathrm{n}} 2000$ g.mol $\left.{ }^{-1}\right):{ }^{1} \mathrm{H}$ NMR spectra $\left(\delta\right.$, ppm) in $\mathrm{CHCl}_{3}-\mathrm{d}_{1}: \mathrm{CH}_{2}-\mathrm{O}$ 3.75-3.45, $\mathrm{OH}$ end group 2.61 and $\mathrm{O}-\mathrm{CH}_{3}$ end group 2.16 .

Human cervix epithelioid carcinoma cell line (HeLa) was obtained from the tissue culture collection of the SAP Institute (Turkey). Cell culture flasks and other plastic material were purchased from Corning (USA). The growth medium, which is Dulbecco Modified Medium (DMEM) without L-glutamine supplemented fetal calf serum (FCS), and Trypsin-EDTA were purchased from Biological Industries (Israel). M30 CytoDEATH antibody (Roche). 


\subsection{Synthesis}

Boron-contaning copolymer (C1-B) was synthesized by the partially amidolysis of succinic anhydride units of alternating copolymer $\mathrm{C} 1$ with $\mathrm{EAPB}$, containing a primary amine group, in the 1,4-dioxane solution at $40^{\circ} \mathrm{C}$ for $3 \mathrm{~h}$ under nitrogen atmosphere at molar ratio of $\mathrm{C} 1$ :EAPB $=2: 1$. Approbriate quantities of $\mathrm{C} 1$ and $\mathrm{EAPB}$, solvent were placed in a standard Pyrex-glass tube and flushed with dried nitrogen gas for at leeast $3 \mathrm{~min}$, then placed in a carousel type microreactor with a thermostated heater and magnetic mixer. The resulting copolymer C1-B was isolated from reaction mixture by precipitating with diethyl ether. Purification of copolymers was done by dissoving in dioxane and reprecipitating in diethyl ether, extraction with hexane and draying under vacuum at $50^{\circ} \mathrm{C}$ until constant weight.

PEO macrobranched copolymer (C1-B-PEO) was synthesized by the esterification of anhydride units of partially amidolysed C1-B copolymer with PEO, containing an end hydoxyl group, in the same conditions using in our previous publications $[5,37]$.

\subsection{Characterization}

FTIR spectra of the organoboron copolymers (KBr pellet) were recorded with FT-IR Nicolet 510 spectrometer in the $4000-400 \mathrm{~cm}^{-1}$ range, where 30 scans were taken at $4 \mathrm{~cm}^{-1}$ resolution. ${ }^{1} \mathrm{H}\left\{{ }^{13} \mathrm{C}\right\}$ NMR spectra were performed on a JEOL 6X-400 (400 MHz) spectrometer with DMSO- $d_{6}$ as a solvent at $25^{\circ} \mathrm{C}$.

The differential scanning calorimetry (DSC) analysis was performed on a Shimadzu calorimeter (Japan) at a heating rate of $5^{\circ} \mathrm{C} / \mathrm{min}$, under nitrogen atmosphere. The X-ray diffraction (XRD) patterns were obtained from a Rigaku D-Max 2200 powder diffractometer. The XRD diffractograms were measured at $2 \theta$, in the range $1-50^{\circ}$, using a Cu- $\mathrm{K}_{a}$ incident beam $(\lambda=1.5406 \AA)$, monochromated by a Ni-filter. The scanning speed was $1 \% \mathrm{~min}$, and the voltage and current of the X-ray tubes were $40 \mathrm{kV}$ and $30 \mathrm{~mA}$, respectively.

The number of living and dead cells were counted with a haemacytometer (C.A. Hausse \& Son Phluila, USA) at X200 magnification. The number of apoptotic and necrotic cells were determined by Fluorescence Inverted Microscope (Olympus IX70, Japan). The cell images were also recorded using the both above mentions microscopes. Statistical analyses were performed using Student's $t$-test for unpaired data and $P$ values of less than 0.05 were considered significant. Data are presented as means \pm SEM (standard errors of the mean).

\subsection{Cytotoxicity}

For cytotoxicity experiments, HeLa cells and L929 Fibroblast cells respectively. $\left(25 \times 10^{3}\right.$ cells per well) were placed in DMEM by using 24-well plates. Different amounts of copolymers (C1, C1-B and C1-B-PEO) (about $50-500 \mu \mathrm{g} \cdot \mathrm{mL}^{-1}$ in aqueous solutions) were put into wells containing cells, respectively. The plates were kept in the $\mathrm{CO}_{2}$ incubator $\left(37^{\circ} \mathrm{C}\right.$ in $\left.5 \% \mathrm{CO}_{2}\right)$ for $2-24 \mathrm{~h}$; the medium was replaced with fresh medium, and incubated at the same conditions for $24 \mathrm{~h}$. Following of this incubation, HeLa cells and L929 Fibroblast cells were harvested with trypsin-EDTA, and then were dyed with trypan blue [41]. The viable cells were counted with a haemacytometer (C.A. Hausse \& Son Phluila, USA), using light microscope.

\subsection{Hematoxylen/Eosin Staining}

HeLa cells and L929 Fibroblast cells $\left(25 \times 10^{3}\right.$ cells per well) were placed in DMEM by using 24-well plates. After treating with different amount functional copolymers (C1, C1-B and C1-B-PEO) (about 50-500 $\mu \mathrm{g} \cdot \mathrm{mL}^{-1}$ in aqueous solutions) for 2-24 hours period, the medium was removed, the cells washed with distilled water and fixed in ethanol, and stained with Hematoxylen/Eosin. After staining, the cells were observed by light microscopy. By this way, cellular and nuclear morphology have been shown in cultured cells stained with Hematoxylen/Eosin.

\subsection{Analysis of Apoptotic and Necrotic Cells}

Double staining were performed to quantify the number of apoptotic cells in culture on basis of scoring of apoptotic cell nuclei. HeLa cells and L929 Fibroblast cells $\left(25 \times 10^{3}\right.$ cells per well) were placed in DMEM by using 24-well plates. After treating with different amount functional copolymers (C1, C1-B and, C1-B-PEO) (about

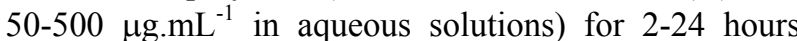
period, both attached and detached cells were collected, then washed with PBS and stained with Hoechst dye 3342 $\left(2 \mu \mathrm{g} \cdot \mathrm{mL}^{-1}\right)$, propodium iodide (PI) $\left(1 \mu \mathrm{g} \cdot \mathrm{mL}^{-1}\right)$ and DNAse free-RNAse $\left(100 \mu \mathrm{g} \cdot \mathrm{mL}^{-1}\right)$ for $15 \mathrm{~min}$ at room temperature. After that $10-50 \mu \mathrm{L}$ of cell supension was smeared on slide and coverslip for examination by fluorescence microscopy $[42,43]$. The nuclei of normal cells were stained light blue but apoptotic cells were stained dark blue by the hoechst dye. The apoptotic cells were identified by their nuclear morphology as a nuclear fragmentation or chromatin condensation. Necrotic cells were staining red by PI. Necrotic cells lacking plasma membrane integrity and PI dye cross cell membrane, but PI dye don't cross non necrotic cell membrane. The number of apoptotic and necrotic cells in 10 randomly chosen microscopic fields were counted and the result expressed as a ratio of apoptotic and necrotic to normal cells.

\subsection{M30 Immunostaining}

The percentage of apoptotic cells was determined by M30 CytoDEATH antibody [44]. This is a monoclonal mouse immunoglobulin (Ig) G2b antibody (clone M30; Roche, 
Mannheim, Germany) that binds to a caspase-cleaved, formalin-resistant epitope of cytokeratin 18 cytoskeletal protein. The immunoreactivity of the M30 antibody is confined to the cytoplasm of apoptotic cells. HeLa cells $\left(25 \times 10^{3}\right.$ cells per well), treated with $\mathrm{C} 1, \mathrm{C} 1-\mathrm{B}$ and, $\mathrm{C} 1-\mathrm{B}-\mathrm{PEO}$ copolymers (about $50-500 \mu \mathrm{g} . \mathrm{mL}^{-1}$ in aqueous solutions) for about $2-24 \mathrm{~h}$, were fixed in $10 \%$ neutral-buffered formalin for $15 \mathrm{~min}$, treated with $0.3 \%$ hydrogen peroxide in methanol for $10 \mathrm{~min}$ to block the endogenous peroxidase activity, washed in the standard phosphate buffer solution, and then incubated with M30 antibody at room temperature for $1 \mathrm{~h}$. In negative controls, preimmune mouse serum instead of primary antibody was used. Immunoreactions were revealed by the avidin-biotin complex technique using diaminobenzidine (DAB) as substrate. We counted the number of M30positive cytoplasmic staining cells in all fields found at x400 final magnification. For each image, three randomly selected microscopic fields were observed, and at least 100 cells/field were evaluated. M30 CytoDEATH antibody was not sensetive to L929 Fibroblast. On account of this reason, M30 CytoDEATH antibody did not applied to L929 Fibroblast cells.

\section{RESULTS AND DISCUSSION}

\subsection{Synthesis and Characterization of Organoboron Functional Copolymers}

Boron-containing bioengineering functional copolymer (C1-B) and its $\alpha$-hydoxy- $\omega$-methoxy-poly(ethylene oxide) (PEO) long branched derivatives were synthesized by (1) amidolysis of succinic anhydride units of biocompatible poly(MA-alt-MVE) alternating copolymer (C1) with EAPB containing a primary amine group, and (2) esterification (grafting) of free anhydride units of partially amidolysed C1-B copolymer with PEO, containing an end hydoxyl group, respectively. General scheme of synthesis of the organoboron functional copolymer and its PEO branched derivative can be represented as follows (Scheme 1).

The synthesized boron-containing copolymers contain a combination of hydrophilic/ hydrophobic linkages, free carboxylic groups, positive charges and ionized organoboron linkage as antitumor sities, along with an ability to interact with canser biomacromolecules, especially with HeLa cells. The chemical and physical structure, composition and properties (temperature-responsiveness, glass-transition, melting and degradation temperatures, andantitumor activity and cytotoxicity) of synthesized copolymers were characterized by spectroscopy (FTIR, ${ }^{1} \mathrm{H}$ and ${ }^{13} \mathrm{C} \mathrm{NMR}$ ), viscometry, DSC, X-ray diffraction and Fluorescence microscopy analyses.

The results of chemical structural analysis of the syn thesized organoboron copolymers FTIR (KBr pellet) and $\left({ }^{1} \mathrm{H}\right.$ and ${ }^{13} \mathrm{C}$ ) NMR spectroscopy (in DMSO- $d_{6}$ solution) were summarized in Table 1 (FTIR analysis data for $\mathrm{C} 1-\mathrm{B})$ and illustrated in Figure 1 (NMR spectra of C1-B) and Figure 2 (FTIR spectra of C1-B-PEO). The formation of amide, carboxyl and organoboron groups in the structure of $\mathrm{C} 1-\mathrm{B}$ copolymer as results of amidolysis reaction was confirmed by apearance of the correspoded characteristic absorption bands for each monomer unit and diphenylboronic fragment in the spectra. Absorption



Scheme 1. Schematic representation of the synthesis routes of organoboron functional copolymers (C1-B and C1-B-PEO) by the amidolysis of poly(MA-alt-MVE) $(\mathrm{C} 1)$ with organoboron amine (AEPB) and esterification of poly (MA-alt-MVE)- $g$ -AEPB) (C1-B) with PEO, respectively.

Table 1. The results of FTIR analysis organoboron functional copolymer: Poly(MA-alt-MVE)-g-AEPBA) (C1-B).

\begin{tabular}{ll}
\hline Absorption bands $\left(\mathrm{cm}^{-1}\right)$ & Band assignments \\
\hline MA unit & \\
$1980-1925(\mathrm{w})$ & $\mathrm{C}=\mathrm{O}$ (overtones) \\
$1864(\mathrm{~m}-\mathrm{s}), 1781(\mathrm{vs})$ & $\mathrm{C}=\mathrm{O}$ stretching (anhydride) \\
$1227(\mathrm{~s}$, broad), $1094(\mathrm{~s})$ & $\mathrm{C}-\mathrm{O}$ and C-O-C bands \\
$650(\mathrm{w})$ & $\mathrm{CH}$ (in chain backbone) \\
MVE unit & \\
$2942(\mathrm{~m}-\mathrm{s})$ & $\mathrm{CH}_{3} \mathrm{C}-\mathrm{H}$ stretching \\
$2854(\mathrm{~m})$ & $\mathrm{CH}_{2} \mathrm{C}-\mathrm{H}$ (chain backbone) \\
$1475-1416(\mathrm{~m})$ & $\mathrm{CH}_{2}$ and $\mathrm{CH}_{3}$ deformation \\
$1372(\mathrm{~m})$ & $\mathrm{CH}_{3}$ deformaton (in O-CH $\left.{ }_{3}\right)$ \\
$975(\mathrm{~m})$ & $\mathrm{CH}$ rocking \\
$926(\mathrm{vs})$ & $\mathrm{C}-\mathrm{O}$ deformation \\
$735(\mathrm{~m}-\mathrm{w}), 720(\mathrm{w})$ & $\mathrm{CH}$ and CH ${ }_{3}$ deformation \\
Maleamide unit & \\
$1736(\mathrm{~m}-\mathrm{s})$ & $\mathrm{C}=\mathrm{O}$ strtching (in $-\mathrm{COOH})$ \\
$1575-1510(\mathrm{~m}-\mathrm{w})$ & $\mathrm{COO}$ stretching (H-bonding) \\
$1650(\mathrm{~m}), 1720(\mathrm{~m}-\mathrm{w})$ & $\mathrm{NH}-\mathrm{C}=\mathrm{O}$ amide $\mathrm{I}$ band \\
$1315(\mathrm{w})$ & amide III band \\
Organoboron linkage & \\
$3240(\mathrm{w}), 3100,1600(\mathrm{~m})$ & $\mathrm{CH}=($ in aromatic ring) \\
$1545(\mathrm{~m}-\mathrm{w})$ & $\mathrm{B}-\mathrm{O}$ stretching \\
$1443(\mathrm{~m}), 1420(\mathrm{w})$ & $\mathrm{B}-\mathrm{Ph}$ aromatic ring \\
$1180(\mathrm{~m})$ & $\mathrm{CH}$ in-put-bending \\
$770(\mathrm{w})$ & $\mathrm{CH}$ out-put-bending \\
$702(\mathrm{~m})$ & $\mathrm{O}-\mathrm{B}-\mathrm{Ph}$ aromatic ring \\
\hline &
\end{tabular}


bands at 1864 and $1781 \mathrm{~cm}^{-1}$, relating to $\mathrm{C}=\mathrm{O}$ groups of free anhydride units, indicated the partially amidolysis of these units as shown in Scheme 1.

From the comparative analysis of ${ }^{1} \mathrm{H}$ and ${ }^{13} \mathrm{C}$ NMR spectra of virgin alternating copolymer $(\mathrm{C} 1)$ and its organoboron derivative (C1-B) (Figure 2a, 2b), the following changes of the characteristic signals were observed: unlike the spectra of $\mathrm{C} 1$ copolymer having the peaks from chemical shifts of the $\mathrm{CH}$ and $\mathrm{CH}_{2}$ backbone and $\mathrm{CH}_{3}$ (in methoxy group) protons new signals from protons of amide $\mathrm{NH}, \mathrm{COOH}$ and phenyl groups (in or ganoboron linkage) were appeared in the spectra of organoboron copolymer (C1-B). More detailed informations about micristructure of $\mathrm{C} 1-\mathrm{B}$ copolymer were pre-pared by analysis of ${ }^{13} \mathrm{C}$ NMR spectra (Figure 2c). The following chemical shifts $(\delta, \mathrm{ppm})$ of carbon atoms were observed in the spectra: $174.4 \quad(-\mathbf{C}=\mathrm{O}$ of the maleamide and anhydride units), 128-136 (-B- $\mathbf{C}_{6} \mathrm{H}_{5}$ mono-substitued benzene ring), $77.2(-\mathrm{CH}-\mathrm{NH}$ in organoboron linkage), $58.01 \quad(-\mathrm{CH}-\mathrm{O}), 49.08$ (- $\mathrm{CH}-$ $\mathbf{C H}$-chain backbone), $30.3\left(-\mathrm{CH}_{3}-\mathrm{O}\right)$, and $30.15\left(-\mathrm{CH}_{2}\right)$.

Chemical structure of $\mathrm{C} 1-\mathrm{B}-\mathrm{PEO}$ long branched copolymer was confirmed by the appearance in the FTIR spectra (Figure 3) the following characteristic absorption bands $\left(\mathrm{cm}^{-1}\right)$ : 3400 (strong broad peak for $\mathrm{OH}$ in $\mathrm{H}$ bonded carboxyl groups), 2933-2735 for $\mathrm{C}-\mathrm{H}$ stretching in $\mathrm{CH}_{2}$ and $\left.\mathrm{CH}_{3}\right), 2667$ and $2600(\mathrm{C}-\mathrm{H}$ stretching in $\mathrm{CH}_{2}-\mathrm{O}$ of PEO branched segments), 2280 and 2135 (Fermi doublet for $\mathrm{C}-\mathrm{N}$ band), 1986 and 1966 (overtones of $\mathrm{C}=\mathrm{O}), 1746(\mathrm{C}=\mathrm{O}$ of ester groups $), 1710(\mathrm{C}=\mathrm{O}$ of carboxyl groups), $1630(\mathrm{NH}-\mathrm{C}=\mathrm{O}$ amide $\mathrm{I}$ band), 1592 (phenyl groups), 1558 (H-bonded $\mathrm{COO}^{-}$stretching), 1545 (weak peak for B-O stretching), 1490 (C-H deformation for $\mathrm{CH}_{2}-\mathrm{O}$ in PEO branches $), 1480$ and $1466\left(\mathrm{CH}_{2}\right.$ deformation), 1450 (B-Ph aromatic ring), 1405 (amide III band), 1372 and $1352\left(\mathrm{CH}_{3}\right.$ deformation in $\left.\mathrm{O}-\mathrm{CH}_{3}\right), 1115$ (broad peak for $\mathrm{C}-\mathrm{O}$ band in $\mathrm{CH}_{2}-\mathrm{O}$ and $\mathrm{CH}_{3}-\mathrm{O}$ of $\mathrm{PEO}$ and MVE units, respectively), 948 (strong peak for $\mathrm{C}-\mathrm{O}$ deformation in PEO branchs), and etc.

The comparative analysis of the XRD patterns of alternating copolymer and its organoboron derivative show a significant difference between physical structures of these copolymers (Figure 3). C1 copolymer has an amorphous structure, while $\mathrm{C} 1-\mathrm{B}$ copolymer exhibits pseudo-crystallinity behavior (without re-crystallization process due to macromolecular physical interactions via H-bonding, hydrophobic-hydrophilic interactions, etc.) with degree of pseudo-crystallinity $\chi_{c}=26.2 \%$ (by XRD analysis), glass-transition $T_{\mathrm{g}}$ and pseudo-melt phase transition $T_{\mathrm{m}}$ at $84.2{ }^{\circ} \mathrm{C}$ and $136.3{ }^{\circ} \mathrm{C}$, respectively (by DSC analysis). It can be proposed that the producing the amphiphilic organoboron linkages in side chain of copolymer causes a formation of hydrophilic/hydrophobic balance, more polar amide and carboxyl groups, which are able to form strong $\mathrm{H}$-bonded segments, and therefore, self-assembled suramacromolecular structure of C1-B copolymer as in other organoboron polymer systems [37].

\subsection{Cytotoxicity of the Copolymer and its B-Containing and PEO Branched Derivatives}

In this study, the comparative analysis of HeLa cells (cancel cells) and L929 Fibroblast cells (normal cells) has been investigated. The cytotoxicities of $\mathrm{C} 1$ copolymer and corresponding $\mathrm{C} 1-\mathrm{B}, \mathrm{C} 1-\mathrm{B} / \mathrm{PEO}$ derivatives were inquired about the utility for antitumor drugs. Figures 4 and 5 give the number of viable cancer and normal cells in each group after incubation of the cells with copolymer and organoboron copolymers at their different concentrations for $24 \mathrm{~h}$ incubating time in cell culture media, respectively. Under the same conditions, the wells containing cells without copolymers were also studied as a control. The following important results can be drawn from this graph which is illustrated in these figures. The $\mathrm{C} 1$ copolymer does not exhibit any observable toxicity in the chosen range of copolymer concentration. The toxicity of polymers containing boron (C1-B and C1-B-PEO) was significant, most probably due to hydrogen bonding supramacromolecular structure of these copolymers containing a combination of hydrophilic/hydrophobic linkages, free carboxylic groups, which are formed after partial amidolysis of anhydride containing copolymer $\mathrm{C} 1$ and full hydrolysis of free anhydride units in the chosen physiological medium where positive charges and ionized organoboronoxy groups also exist as antitumor sites along with an ability to interact with cells.

It was observed that an increase of $\mathrm{C} 1-\mathrm{B}$ and $\mathrm{C} 1$ $\mathrm{B}-\mathrm{PEO}$ concentrations in each well caused higher degree of dying cells as compared to virgin $\mathrm{C} 1$ copolymer tested under the same conditions. C1-B copolymer exhibits relatively higher in vitro cytotoxicity than $\mathrm{C} 1-\mathrm{B}-\mathrm{PEO}$ branched copolymer which can be explained by the higher content of organoboron linkages in C1-B copolymer. It is important to note that the boron containing side chain linkages, rather than the individual copolymers, increase the cytotoxicity more profoundly; an important feature which has a significant role in leading us to the present study. C1 copolymer had less toxicity compared to cultured cells at various quantities and different incubation times. On the contrary, the toxicity of $\mathrm{C} 1-\mathrm{B}$ and C1-B-PEO organoboron copolymers towards the HeLa cells increased by increasing their quantity from 50 to 500 $\mu \mathrm{g} . \mathrm{mL}^{-1}$, whereas, no significant change was observed with varying time. According to Figure 4, C1 did not show high toxicity at all although the copolymer amount was increased from 50 to $500 \mu \mathrm{g} . \mathrm{mL}^{-1}$ whilst, a significant toxicity of C1-B andC1-B-PEO (100 $\mu \mathrm{g} . \mathrm{mL}^{-1}$ and above) started to be observed when cancer and normal cells (Figure 5) were incubated for about $4 \mathrm{~h}$. As the amount of boron con taining polymers and their incubtion 


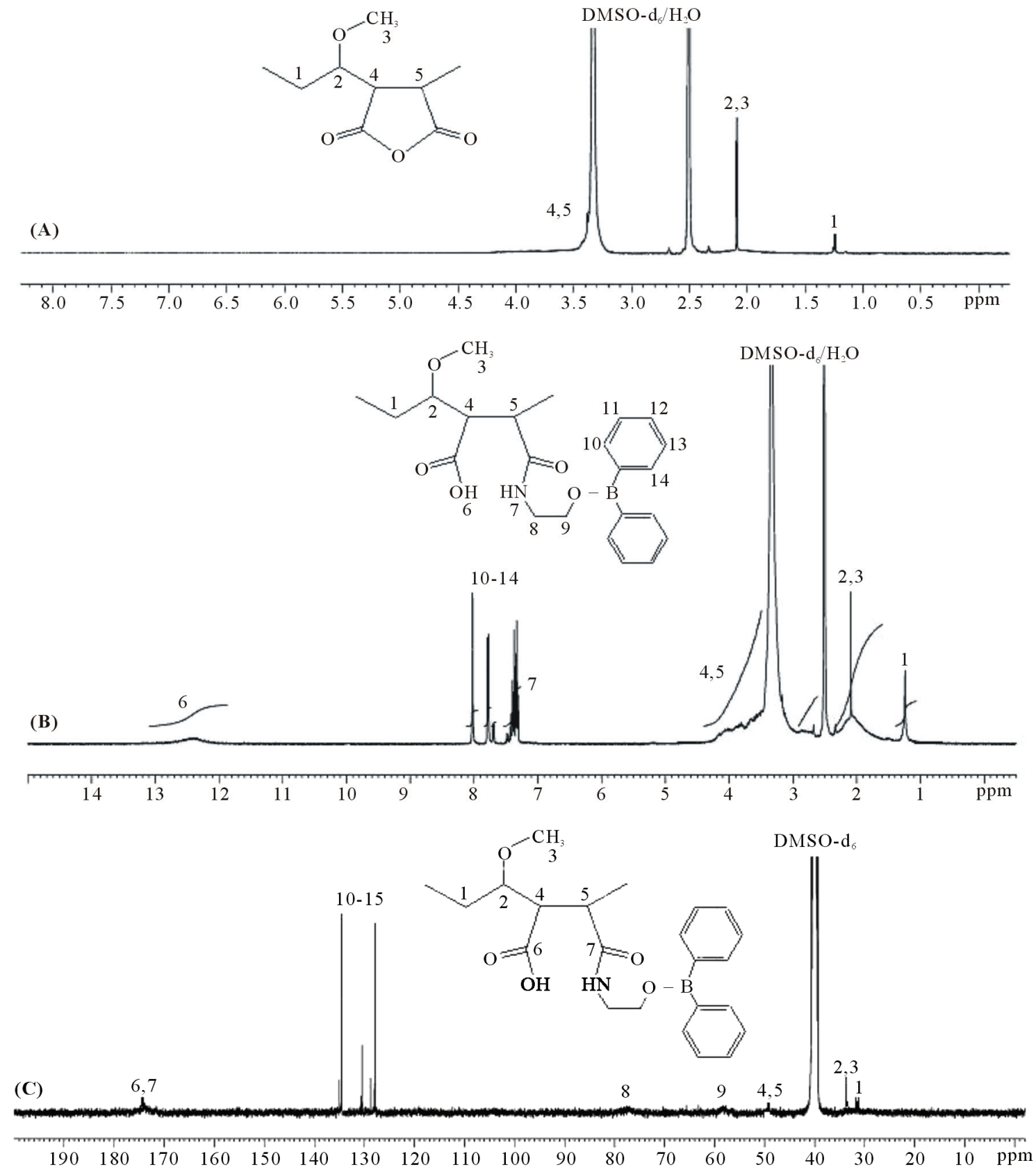

Figure 1. ${ }^{1} \mathrm{H}$ NMR spectra of (A) C1 copolymer and (B) C1-B organoboron copolymer; (C) ${ }^{13} \mathrm{C}$ NMR spectra of C1-B copolymer.

time increased, toxicity to cultured cells was increased. $\mathrm{C} 1-\mathrm{B}-\mathrm{PEO}$ and especially $\mathrm{C} 1-\mathrm{B}$ showed higher toxicity at $500 \mu \mathrm{g} . \mathrm{mL}^{-1}$. Thus, it can be concluded that virgin $\mathrm{C} 1$ alternating copolymer does not exhibit any toxic effect on cultured HeLa cells, whereas, its organoboron and PEO branched derivatives are definitely toxic to cells. In particular, C1-B copolymer containing relatively high amount of organoboron linkages exhibits high toxicity toward cancer cells compared to normal cells at 500 $\mu \mathrm{g} . \mathrm{mL}^{-1}$ for $24 \mathrm{~h}$.

\subsection{Staining Results}

The important observations can be summarized as follows: we checked for apoptosis or necrosis with double staining (Hoescht 3342 and PI), M30 immunostaining for cancer cells. For the morphological observations, cancer and normal cells were stained by hematoxylen-eosin.

\subsection{Hematoxylen-Eosin Staining Results}

In this study, C-1 copolymers treated cancer and normal 


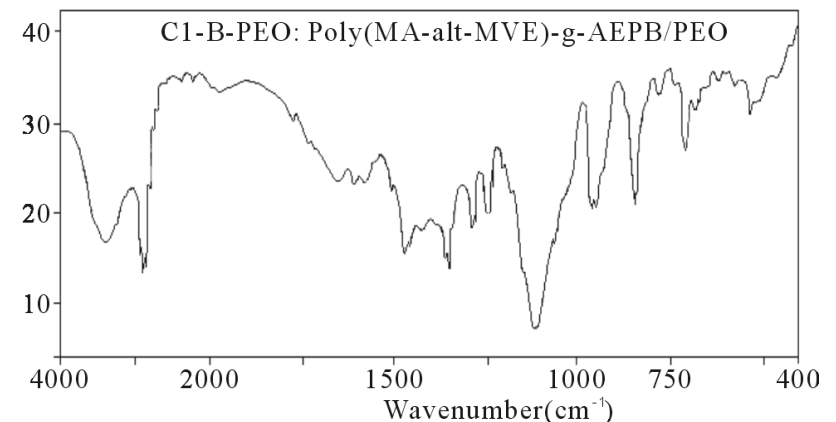

Figure 2. FTIR spectra of PEO macrobranched organoboron copolymer (C1-B-PEO).
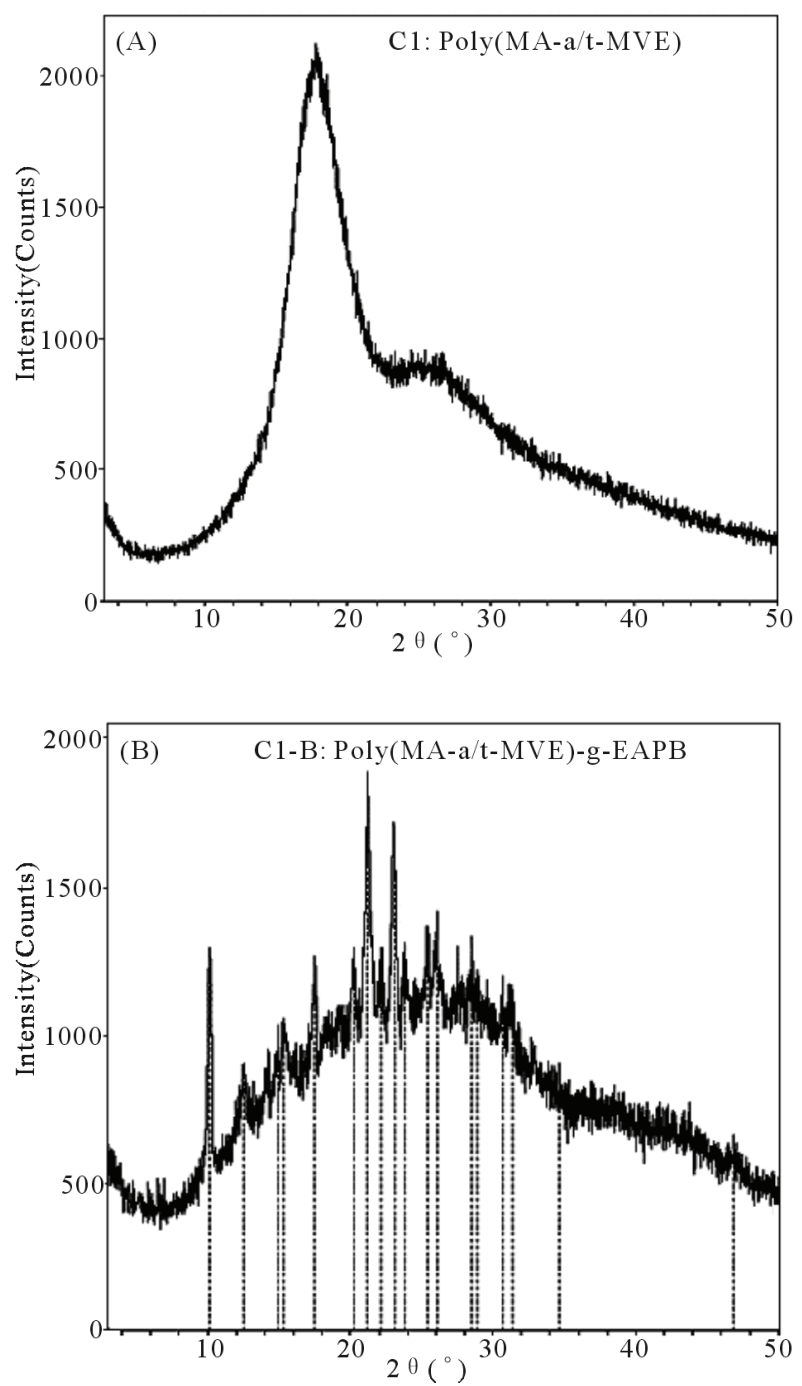

Figure 3. XRD patterns of (A) alternating copolymer (C1) and (B) its branched organoboron derivative.

cells have intact nucleus of about 50-200 $\mu \mathrm{g} . \mathrm{mL}^{-1}$ concentration during 2-14 $\mathrm{h}$ incubation. Cell morphology has not been changed at the same concentration for 2-14 h (Figure 6b). While C1-B and C1-B-PEO copolymers

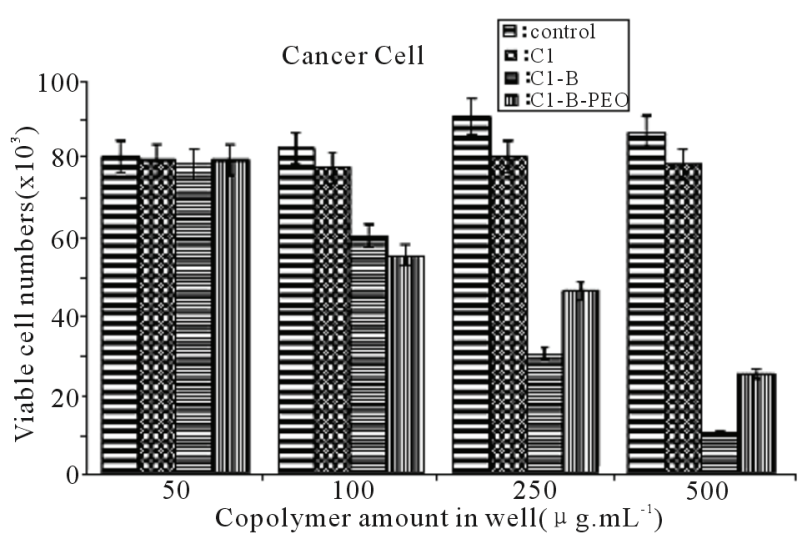

Figure 4. In vitro cytotoxicity of $\mathrm{C} 1, \mathrm{C} 1-\mathrm{B}$ and $\mathrm{C} 1-\mathrm{B}-\mathrm{PEO}$ copolymers with different amount at $24 \mathrm{~h}$ incubation. Number of viable HeLa cells in wells. Results are presented as means \pm SEM. ${ }^{*}$ Significant difference from control $(p<0.05)$.

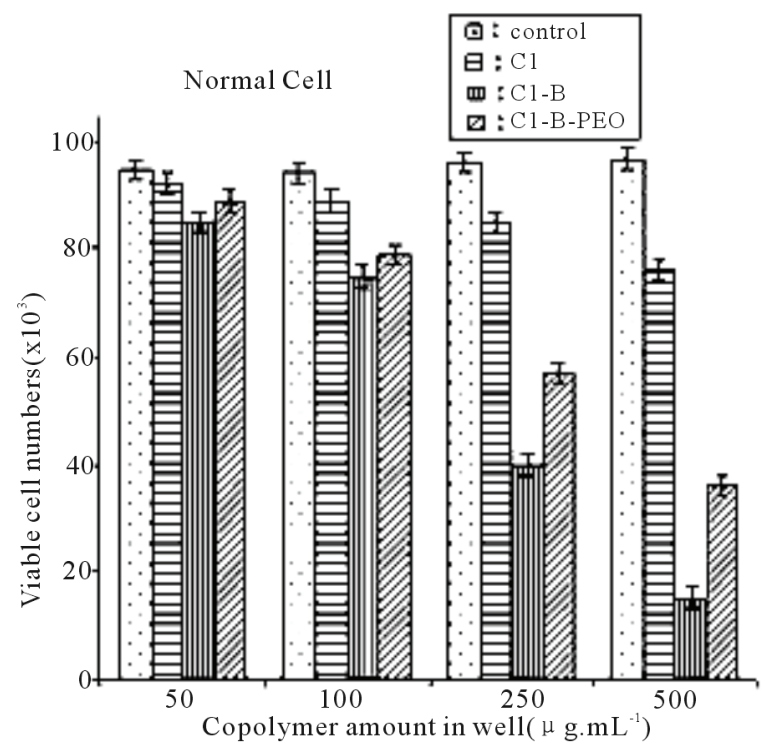

Figure 5. In vitro cytotoxicity of $\mathrm{C} 1, \mathrm{C} 1-\mathrm{B}$ and $\mathrm{C} 1-\mathrm{B}-\mathrm{PEO}$ copolymers with different amount at $24 \mathrm{~h}$ incubation. Number of viable L929 Fibroblast cells in wells. Results are presented as means \pm SEM. ${ }^{*}$ Significant difference from control $(p<0.05)$.

treated HeLa cells has no morphological changes at 50-200 $\mu \mathrm{g} \cdot \mathrm{mL}^{-1}$ concentration for about 2-4 h, they have vacuole formation in their cytoplasms with $\mathrm{C} 1-\mathrm{B}$ copolymer between 6-12 hours (Figure 6c). Vacuole formations determined rarely in normal cells (Figure 6e, f). In addition, cell membranes have lysed with $\mathrm{C} 1-\mathrm{B}$ copolymer around $12-24 \mathrm{~h}$ but, there was no change in their nuclei of cancer and normal cells. Moreover, some of the cells (30\% and $15 \%$ for HeLa and fibroblast, respectively) have been detached from the well. Unaffected cells displayed similar morphological characteristics as with untreated (control) cells. 


\subsection{Double Staining and $M 30$ Immunostaining Results}

In this study, if the HeLa and L929 Fibroblast cells treated by $\mathrm{C} 1, \mathrm{C} 1-\mathrm{B}, \mathrm{C} 1-\mathrm{B}-\mathrm{PEO}$ copolymers at low conce ntration for a short time, the number of apoptotic and necrotic cells was not high (Tables 2 and 3). However, if the polymer concentration and incubation time were increased, the number of apoptotic and necrotic cells was increased as well. Especially, the number of apoptotic and necrotic cells was increased when they were treated by $\mathrm{C} 1-\mathrm{B}$ copolymer at $500 \mu \mathrm{g} \cdot \mathrm{mL}^{-1}$ concentration in cancer cell culture for $24 \mathrm{~h}$ (Table 2). The number of apoptotic and necrotic Fibroblast cells was not increased according to HeLa cells at the same concentration (Table 3 ). If cells were treated by the other copolymer under similar conditions, their apoptotic index was below $30 \%$. The results obtained at $500 \mu \mathrm{g} . \mathrm{mL}^{-1}$ concentration for $24 \mathrm{~h}$ are shown in Table 2. Meanwhile, apoptotic HeLa cells were immunostained by M30 antibody (Figure 7a, 7b). The double staining and M30 immunostaining results were similar to each other in HeLa cells. Apoptotic indexes of HeLa cells for M30 immunostaining were 12\% for C1, 45 $\%$ for C1-B, $23 \%$ for C1-B-PEO at $500 \mu \mathrm{g} \cdot \mathrm{mL}^{-1}$ and $24 \mathrm{~h}$ incubation. Apoptotic L929 Fibroblast cells were stained only double staining method (Table 3 ). In addition to these polymers, especially boron containing polymers had toxic effects towards cancer and normal cells. But toxic effect of boron containing polymers was lower to normal cells than cancer cells. After an incubation at 50-500 $\mu \mathrm{g} . \mathrm{mL}^{-1}$ for $24 \mathrm{~h}$ period, $\mathrm{C} 1$ resulted in less apoptosis, while incubation with $\mathrm{C} 1-\mathrm{B}$ and $\mathrm{C} 1-\mathrm{B}-\mathrm{PEO}$ at the same concentration and incubation time led to high apoptosis of HeLa cells compared to L929 Fibroblast cells. Both C1-B and C1-B-PEO may well inhibit cell growth and viability in HeLa (Figure 7b, c, d) and L929 Fibroblast cells (Figure 7e, f). One the other hand, around 50-500 $\mu \mathrm{g} \cdot \mathrm{mL}^{-1}$ of $\mathrm{C} 1-\mathrm{B}$ and $\mathrm{C} 1-\mathrm{B}-\mathrm{PEO}$ copolymer contents for $24 \mathrm{~h}$ gave rise to an increase in necrosis stained with PI dye (Figure 7c, e and Tables 2 and 3). It is important to note that incubation for $24 \mathrm{~h}$ with $500 \mu \mathrm{g}$. $\mathrm{mL}^{-1} \mathrm{C} 1-\mathrm{B}$ produced apoptosis supporting its high toxicity and necrotic effect. Furthermore, incubation without polymers as control cells resulted in a few PI-positive cells. Whereas, cells exposed to C1-B and C1-B-PEObecame highly PI-positive, suggesting that they were in necrosis. HeLa cells incubated with a high dose of boron containing copolymers resulted in rupture of cell membrane at around 12-24 $\mathrm{h}$ incubation period. Cell cytoplasm was discharged out of HeLa cells. On the otherhand, great of number vacuole originated in most of HeLa cells cytoplasma. It may have given rise to metabolicchanges of cells, affected by boron containing copolymers. C1-B copolymer was more toxic than virgin counder the testing conditions determined by us.
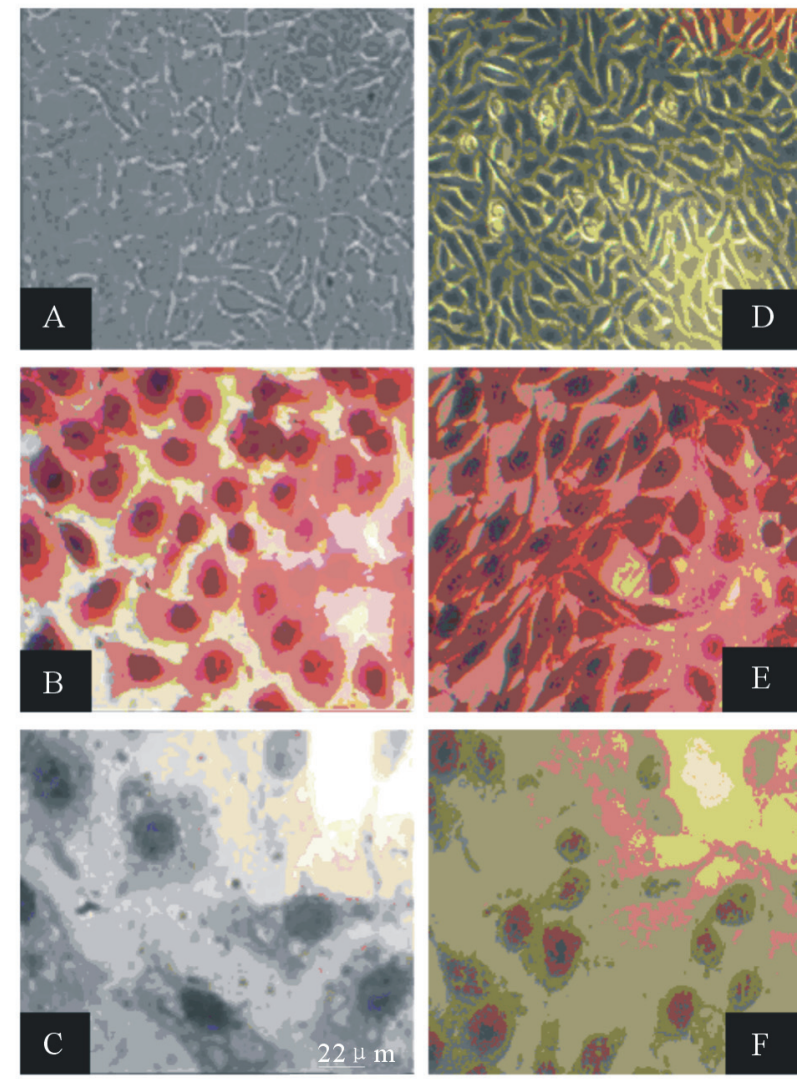

Figure 6. Light microscope image of (A) non stained HeLa cell culture as a control, (B) C1-B-PEO copolymer/HeLa cells conjugate (stained with hematoxilen-eosin dye); dense spots were showed nucleus of cells, and distinct violet were indicated cytoplasma of cells as a control, (C) Light microscope image of vacuole of HeLa cells cytoplasma; dense spots were showed nucleus of cells in C1-B copolymers $\left(500 \mu \mathrm{g} \cdot \mathrm{mL}^{-1}\right.$ consantration $)$ at $24 \mathrm{~h}$ incubation. Light microscope image of (D) non stained L929 Fibroblast cell culture as a control, (B) C1-B-PEO copolymer/L929 Fibroblast cells conjugate (stained with hematoxilen-eosin dye); dense spots were showed nucleus of cells, and distinct violet were indicated cytoplasma of cells as a control, (C) Light microscope image of vacuole of L929 Fibroblast cells cytoplasma; dense spots were showed nucleus of cells in C1-B copolymers $\left(500 \mu \mathrm{g} \cdot \mathrm{mL}^{-1}\right.$ consantration) at $24 \mathrm{~h}$ incubation. Images (A) and (D) taken under X200 magnification, others images taken under $\mathrm{x} 400$ magnification.

\section{CONCLUSIONS}

This work has attempted to develop novel bioengineering functional organoboron copolymers (C1-B and C1-BPEO), namely, amphiphilic macromolecules of which contained hydrophilic/hydrophobic fragments, ethylene amidodiphenylborinate linkages, long branched PEO segments and free carboxylic groups with an ability to conjugate with cancer HeLa cells. These copolymers were synthesized by amidolysis and esterification of anhydride units of poly(MA-alt-MVE) (C1) as a bio- 
Table 2. The comparative analysis of apoptotic and necrotic HeLa cell index for copolymer $(\mathrm{C} 1)$, organo-boron $(\mathrm{C} 1-\mathrm{B})$ and organoboron PEO branched (C1-B-PEO) copolymers at $24 \mathrm{~h}$ incubation.

\begin{tabular}{ccc}
\hline $\begin{array}{c}\text { Polymer amount } \\
\left(\mu \mathrm{g} \cdot \mathrm{mL}^{-1}\right)\end{array}$ & $\begin{array}{c}\text { Apoptotic } \\
\text { cells }(\%)\end{array}$ & $\begin{array}{c}\text { Necrotic } \\
\text { cells }(\%)\end{array}$ \\
\hline C1 & $3 \pm 2$ & $4 \pm 2$ \\
control & $3 \pm 1$ & $5 \pm 1.5$ \\
50 & $6 \pm 1.5$ & $9 \pm 3$ \\
100 & $8.5 \pm 1$ & $13.8 \pm 1.5$ \\
250 & $15 \pm 2$ & $27 \pm 3$ \\
500 & & \\
C1-B & $5 \pm 3$ & $2 \pm 1$ \\
control & $13 \pm 2$ & $20 \pm 3$ \\
50 & $18 \pm 2.5$ & $31 \pm 4$ \\
100 & $32 \pm 1$ & $41 \pm 2$ \\
250 & $43 \pm 2$ & $53 \pm 3$ \\
500 & & $5 \pm 1.5$ \\
C1-B-PEO & $3.5 \pm 1.5$ & $11 \pm 1.5$ \\
control & $9 \pm 1$ & $16 \pm 2$ \\
50 & $12 \pm 1$ & $25 \pm 3$ \\
100 & $15 \pm 2$ & $43.5 \pm 5$ \\
250 & $28 \pm 2.5$ & \\
\hline 500 & &
\end{tabular}

Table 3. The comparative analysis of apoptotic L 929 Fibroblast cells index for copolymers (C1), organoboron (C1-B) and organoboron PEO branched (C1-B-PEO) copolymers at $24 \mathrm{~h}$ incubation.

\begin{tabular}{ccc}
\hline $\begin{array}{c}\text { Polymer amount } \\
\left(\mu \mathrm{g} \cdot \mathrm{mL}^{-1}\right)\end{array}$ & $\begin{array}{c}\text { Apoptotic } \\
\text { cells }(\%)\end{array}$ & $\begin{array}{c}\text { Necrotic } \\
\text { cells }(\%)\end{array}$ \\
\hline C1 & & \\
control & $2 \pm 1$ & $3 \pm 1$ \\
50 & $3 \pm 1$ & $3 \pm 1.5$ \\
100 & $4 \pm 1$ & $6 \pm 2$ \\
250 & $7 \pm 1$ & $11 \pm 1.5$ \\
500 & $9 \pm 1.5$ & $17 \pm 2$ \\
\hline C1-B & & $2 \pm 1$ \\
control & $2 \pm 1$ & $12 \pm 2$ \\
50 & $7 \pm 2$ & $17 \pm 3$ \\
100 & $12 \pm 2.5$ & $25 \pm 2$ \\
250 & $16 \pm 1$ & $38 \pm 2$ \\
500 & $27 \pm 2$ & \\
\hline C1-B-PEO & & $8 \pm 1$ \\
control & $3 \pm 2$ & $11 \pm 2$ \\
50 & $4 \pm 1$ & $16 \pm 3$ \\
100 & $6 \pm 1$ & $30 \pm 1$ \\
250 & $9 \pm 2$ & \\
\hline 500 & $17 \pm 2.5$ & \\
& &
\end{tabular}

compatible and non toxic polymer matrix with organoboron amine and PEO, respectively. Chemical and physical structure of organoboron copolymers were confirmed by FTIR and ${ }^{1} \mathrm{H}\left({ }^{13} \mathrm{C}\right)$ NMR spectroscopy and $\mathrm{X}$-ray powder diffraction methods. The comparative analysis of novel organoboron functional copolymers with antitumor acivity towards cancer and normal cells was achieved. It was found that unlike the virgin amorphous $\mathrm{C} 1$ copolymer, organoboron copolymer (C1-B) exhibited semi-crystalline phase transition behaviour due to the formation of self-assembled supramacromolecular structures through strong intra-and intermolecular hy-

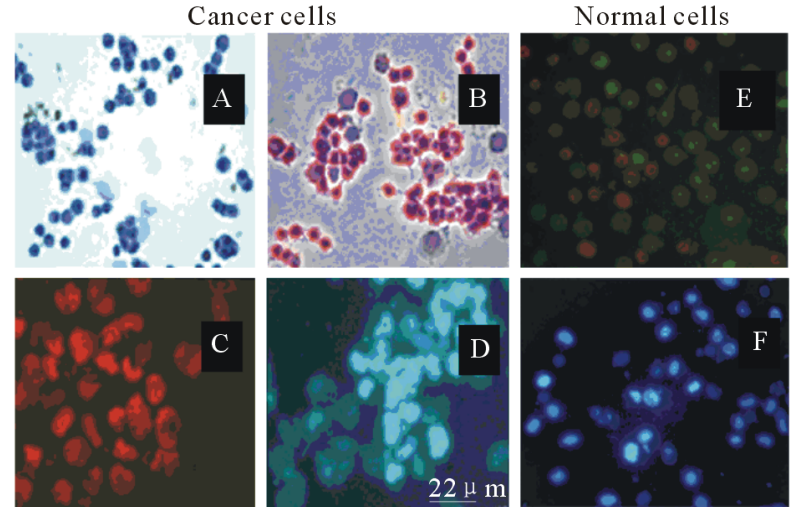

Figure 7. Light microscopy images of (A) virgin (nonapoptotic) HeLa cells as a control group (stained with M30 immunostaining kit), and (B) organoboron copolymer C1-B copolymer/HeLa cells conjugate (stained with M30 immunostaining kit), where brown cytoplasma of cells image indicates the formation of apoptotic cells; Fluorescence microscopy image of $(\mathrm{C})$ nucleus of HeLa cells (stained with PI), where formation of red spots demostrates nucleus of necrotic cells, and (D) nucleus of HeLa cells (stained with Hoescht 3342), where dense spots indicates nucleus of apoptotic cells. Fluorescence microscopy image of (E) nucleus of L929 Fibroblast cells (stained with PI), where formation of red spots demostrates nucleus of necrotic cells and green spots demostrates nucleus of living cells, and (F) nucleus of L929 Fibroblast cells (stained with Hoescht 3342), where dense spots indicates nucleus of apoptotic cells. İmages of Cand D were recorded with $\times 400$ magnification, others image were recorded with $\mathrm{x} 200$ magnification.

drogen bonding. The interactions of these copolymers with HeLa cells were investigated by using a combination of different methods such as cytotoxicity, statistical, hematoxylen/eosin staining, apoptotic and necrotic cell indexes, M30 immunostaining, double staining and M30 immunostaining, light and fluorescence microscopy analyses. In vitro cytotoxicities and antitumor activities of organoboron copolymers (C1-B and C1-B-PEO) against human cervix epithelioid carcinoma cell line (HeLa) was as well evaluated. It was observed that organoboron copolymers exhibited the most apoptotic and necrotic effects against HeLa cells whereas a minor effect relative to cancer cells was observed on L929 Fibroblast cells. Thus the obtained results allow us to propose that synthesized organoboron copolymers containing a combination of non toxic and biocompatibile polymer matrix and long branched PEO segments with functional groups as antitumor sities, can be utilized as therapeutic potential functional copolymer drugs, which are able to form an artificial bioconjugate with HeLa cells, in cancer chemotherapy.

\section{ACKNOWLEDGEMENTS}

The supports of the Turkish National Scientific and Technical Council (TÜBITAK) through project TBAG-2486 and HU Scientific Research 
Foundation (BAB) through the BAB-2601006 project are kindly acknowledged.

\section{REFERENCES}

[1] Albertsson, P.A. (1986) Partition of Cell Particles and Macromolecules. New York, Wiley.

[2] Herold, D.A., Keil, K., Bruns, D.E. (1989) Oxidation of polyethylene glycols by alcohol dehydrogenase.Biochem Pharmacol, 38(1), 73.

[3] Sinha, V.R., Aggarwal, A., Trehan, A. (2004) Biodegradable PEGylated microspheres and nanospheres. Amer J Drug Deliv, 2(3), 157.

[4] Köşeli, V., Rzaev, Z.M.O., Pişkin, E. (2003) Bioengineering functional copolymers. III. Synthesis of biocompatible poly(NIPA-co-MA)-g-PEO/PEI macrocomplexes and their thermostabilization effect on the activity of the enzyme penicillin G acylase. J Polym Sci Part A: Polym Chem, 41(11), 1580.

[5] Mazi, H., Kibarer, G., Emregül, E., Rzaev, Z.M.O. (2006) Bioengineering functional copolymers. IX. Poly[(maleic anhydride-co-hexene-1)-g-poly(ethylene oxide)]. Macromol Biosci, 6(4), 311.

[6] Mazi, H., Emregül, E., Rzaev, Z.M.O., Kibarer, G. (2006) Preparation and properties of invertase immobilized on a poly(maleic anhydride-hexen-1) membrane. J Biomater Sci, Polym Ed, 17, 821.

[7] Rzaev, Z.M.O., Dinçer, S., Pişkin, E. (2007) Functional copolymers of $N$-isopropyl-acrylamide for bioengineering applications. Prog Polym Sci, 32(5), 534.

[8] Butler, G.B. (1992) Cyclopolymerization and cyclopolymerization. New York, Marcel Dekker.

[9] Veron, L., Bignicount, M.C.D., Delair, T., Pichot, C., Mandrand, B. (1996) Syntheses of poly [N-(2,2-dimethoxyethyl)- $N$-methyl acrylamide] for the immobilization of oligo-nucleotides. J Appl Polym Sci, 60(2), 235.

[10] Ladavière, C., Delair, T., Domard, A., Pichot, C., Man-drand, B. (1999) Covalent immobilization of biological molecules to maleic anhydride and methyl vinyl ether copolymers-A physico-chemical approach. $J$ Appl Polym Sci, 71(6), 927.

[11] Chaix, C., Minard-Basquin, C., Delair, T., Pichot, C., and Mandrand, B. (1998) Oligonucleotide synthesis maleic anhydride copolymers covalently bound to silica spherical support and characterization of the on obtained conjugates. J Appl Polym Sci 70(12), 2487.

[12] Volkova, F., Gorshkova, M.Yu., Ivanov, P. E., Stotskaya, L. L. (2002) New scope for synthesis of divinyl ether and maleic anhydride copolymer with narrow molecular mass distribution. Polym Adv Technol, 13(10-12), 1067.

[13] Izumrudov, V.A., Gorshkova, M.Yu., Volkova, F. (2005) Controlled phase separations in solution of soluble poly-electrolyte complex of DIVEMA (copolymer of divinyl ether and maleic anhydride. Eur Polym J, 41(6), 1251.

[14] Ladavière, C., Delair, T., Domard, A., Pichot, C., Mandrand, B. (1999) Covalent immobilization of bovine serum albumin onto (maleic anhydride-alt-methyl vinyl ether) copolymers. J Appl Polym Sci, 72(12), 1565.

[15] Delair, T., Badey, B., Domard, A., Pichot, C., Mandrand, B. (1997) Polym Adv Technol, 8(5), 297.
[16] Patel, H., Raval, D.A., Madamwar, D., Sinha, T.J.M. (1997) Polymeric prodrugs. Synthesis, release study and antim-icrobial properties of polymer-bound acriflavine. Angew Makromol Chem, 245(1), 1.

[17] Patel, H., Raval, D.A., Madamwar, D., Patel, S.R. (1998) Polymeric prodrug: Synthesis, release study and antimicrobial property of poly(styrene-co-maleicanhydride)-bound acriflavine. Angew Makromol Chem, 263(1), 25.

[18] Hirano, T., Todorski, T., Kato, S., Yamamoto, H., Caliceti, P. (1994) Synthesis of the conjugate of superoxide dismutase with the copolymer of divinyl ether and maleic anhydride retaining enzymatic activity. $J$ Control Release, 28(1-3), 203.

[19] Hirano, T., Todorski, T., Morita, R., Kato, S., Ito, Y., Kim, K., Shukla, G., Veronese, F., Maeda, H., Ohashi, S. (1997) Anti-inflammatory effect of the conjugate of superoxide dismutase with the copolymer of divinyl ether and maleic anhydride against rat re-expansion pulmonary edema. $J$ Control Release, 48(2-3), 131.

[20] Maeda, H.H. (1991) SMANCS and polymer-conjugated macromolecular drugs: advantages in cancer chemotherapy. Adv Drug Delivery Rev, 6(2), 181.

[21] Gam, G.-T., Jeong, J.-G., Lee, N.-J., Lee, W., Ha, C.-S., Cho, W.-J. (1995) Synthesis and biological activities of copolymers of $\mathrm{N}$-glycinyl maleimide with methacrylic acid and vinyl acetate. J Appl Polym Sci, 57(2), 219.

[22] Claracq, J., Santos, S., Duhamel, J., Dumousseaux, C., Corpart, J.M. (2002) Rigid interior of styrene-maleic anhydride copolymer aggregates probes by fluorescence spectroscopy. Langmuir, 18(10), 3829.

[23] James, T.D., Sandanayake, S., Shinkay, S. (1996) Saccharide sensing with molecular receptors based on boronic acid. Angew Chem Inter Ed Eng, 35(17), 1910.

[24] Barth, R.F., Yang, W., Rotaru, J.H., Moeschberger, M.L., Boesel, C.P., Soloway, A.H., Joel, D.D., Nawrocky, M.M., Ono, K., Goodman, J.H. (2000) Boron neutron cupture therapy of brain tumors: enchanced survival and cure following blood-brain barrier disruption and intracarotid injection of sodium borocaptate and boronophenyl aniline. Int J Radiat Oncol Biol Phys, 47(1), 209.

[25] Siebert, W. (Ed.) (1887): Advances in Boron Chemistry. Cambridge, Royal Society Chemistry.

[26] Mishima Y. (Ed.) (1996) Cancer Neutron Capture Therapy. New York, Plenum Press.

[27] Kettner, C.A. and Shenvi, A.B. (1984) Inhibition of the serine proteases leukocyte elastase, pancreatic elastase, cathepsin $\mathrm{G}$, and chymotrypsin by peptide boronic acids. $J$ Biol Chem, 259(24), 15106.

[28] Miyazaki, H., Kikuchi, A., Kitano, S., Koyama, Y., Okano, T., Sakurai, Y., Kataoka, K. (1993) Boronate-containing polymer as novel mitogen for lymphocytes. Biochem Biophys Res Commun, 195(2), 829.

[29] Aoki, T., Nagao, Y., Terada, E., Sanui, K., Ogata N., Yamada, N., Sakurai, Y., Kataoka, K., Okano, T. (1995) Endothelial cell differentiation into capillary structures by copolymer surfaces with phenylboronic acid group. $J$ Biomater Sci Polym Ed, 7(7), 539.

[30] Otsuka, H., Uchimura, E., Koshino, H., Okano, T., Kataoka, K. (2003) Anomalous binding profile of pheny-lboronic acid with $N$-acetylneuraminic acid (Neu5Ac) in aqueous solution with varying $\mathrm{pH}$. $J \mathrm{Am}$ 
Chem Soc, 125(12), 3493.

[31] Uchimura, E., Otsuka, H., Okano, T., Sakurai, S., Kataoka, K. (2001) Totally synthetic polymer with lectin-like function: Induction of killer cells by the copolymer of 3-acryl-amidophenylboronic acid with $N, N$-dimethylacrylamide. Biotech Bioeng, 72(3), 307.

[32] Otsuka,H., Ikeya, T., Okano, T., Kataoka, K. (2006) Activation of lymphocyte proliferation by boronatecontaining polymer immobilised on substrate: The effect of boron content on lymphocyte proliferation. Eur Cells Mater, 12(1), 36.

[33] Kataoka, K., Miyazaki, N., Okano, T., Sakurai, Y. (1994) Sensitive glucose-induced change of the lower critical solution temperature of poly $[N, N$-dimethylacrylamideco-3-(acrylamido) phenylboronic acid] in physiological saline. Macromolecules, 27(4), 1061.

[34] Uguzdoğan, E., Denktaş, E.B., Tuncel, A. (2002) RNAsensitive $N$-isopropylacrylamide/vinylphenyl boronic acid random copolymer. Macromol Biosci, 2(5), 214.

[35] Uguzdoğan, E., Kayi, H., Denktaş, E.B., Patir, S., Tuncel, A. (2003) Stimuli-responsive properties of aminophenylboronic acid carrying thermosensitive copolymers. $\mathrm{Po}$ lym Int, 52(5), 649.

[36] Shiomori, K., Ivanov, A.E., Galaev, I.Yu., Kawano, Y., Mattiasson, B. (2004) Thermo-responsive properties of sugar sensitive copolymer of $N$-isopropylacrylamide and 3-(acrylamido)phenylboronic acid Macromol Chem Phys, 205(1), 27.

[37] Rzayev, Z.M.O., Beşkardeş, O. (2007) Boron-containing functional copolymers for bioengineering applications.
Collect Czech Chem Commun, 72(12), 1591.

[38] Kahraman, G., Beşkardeş, O., Rzayev, Z.M.O., Pişkin, E. (2004) Bioengineering functional copolymers. VII. Synthesis and characterization of boron-containing self-assembled supramolecular architectures. Polymer, 45(17), 5813.

[39] Çimen, E.K., Rzayev, Z.M.O., Pişkin, E. (2005) Bioengi-neering functional copolymers. V. Synthesis LCST, and thermal behavior of poly $(N$-isopropylacrylamide-co-p-vinyl-phenylboronic acid). J Appl Polym Sci, 95(3), 573.

[40] Rzayev, Z.M.O., Erdoğan, D., Türk, M., Pişkin, E. (2008) Bioengineering functional copolymers. VIII. Stimuli-responsive boron-containing graft copolymers and their poly(ethylene imine) macrocomplexes and DNA conjugates. J Biol Chem, 36(2), 83.

[41] Türk, M., Dincer, S., Yulug, I.G., Piskin, E. (2004) In vitro transfection of HeLa cells with temperature sensitive polycationic copolymers. J Control Release, 96(2), 325.

[42] Choi, S.-J., Oh, J.-M., Choy, J.-H. (2009) Toxicological effects of inorganic nanoparticle nanoparticles on human lung cancer A549 cells. J Inorg Biochem, 103(3), 463.

[43] Ulukaya, E., Kurt, A., Wood, E.J. (2001) 4-(N-hydroxyphenyl)retinamide can selectively induce apoptosis in human epidermoid carcinoma cells but not in normal dermal fibroblasts.Cancer Invest, 19(2), 145.

[44] McPartland, J.L., Guzail, M.A., Kendall, C.H., Pringle, J.H. (2005) Apoptosis in chronic viral hepatitis parallels histological activity: an immunohistochemical investigation using antiactivated caspase-3 and M30 cytodeath antibody. Int J Exp Pathol, 86(1), 19. 